\title{
An Evaluation of Solidification/Stabilization for Sediments from the Puget Sound Naval Shipyard
}

\author{
Michael G. Channell
}

US Army Corps of Engineers ${ }_{\circledast}$

Engineer Research and Development Center

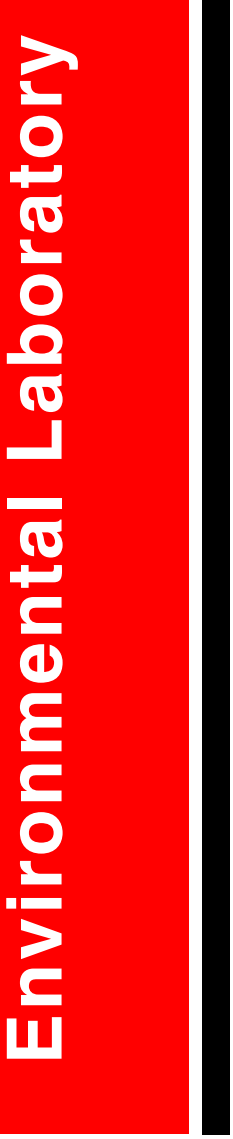


The contents of this report are not to be used for advertising, publication, or promotional purposes. Citation of trade names does not constitute an official endorsement or approval of the use of such commercial products.

The findings of this report are not to be construed as an official Department of the Army position, unless so designated by other authorized documents. 
ERDC/EL TR-00-9

September 2000

\section{An Evaluation of Solidification/Stabilization for Sediments from the Puget Sound Naval Shipyard}

by Michael G. Channell

Environmental Laboratory

U.S. Army Engineer Research and Development Center 3909 Halls Ferry Road

Vicksburg, MS 39180-6199

Final report

Approved for public release; distribution is unlimited 


\section{Engineer Research and Development Center Cataloging-in-Publication Data}

Channell, Michael G.

An evaluation of solidification/stabilization for sediments from the Puget Sound Naval Shipyard / by Michael G. Channell ; prepared for Naval Facilities Engineering Service Center.

36 p. : ill. ; 28 cm. -- (ERDC/EL ; TR-00-9)

Includes bibliographic references.

1. Dredging spoil -- Washington (State) -- Puget Sound Region. 2. Contaminated sediments -Washington (State) -- Puget Sound Region. 3. Contaminated sediments -- Testing. I. United States. Army. Corps of Engineers. II. Engineer Research and Development Center (U.S.) III.

Environmental Laboratory (U.S.) IV. Naval Facilities Engineering Service Center (Port Hueneme, Calif.) V. Title. VI. Series: ERDC/EL TR ; 00-9.

TA7 E8 no.ERDC/EL TR-00-9 


\section{Contents}

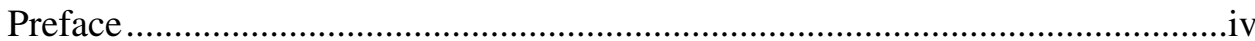

Conversion Factors, Non-SI to SI Units of Measurement......................................vi

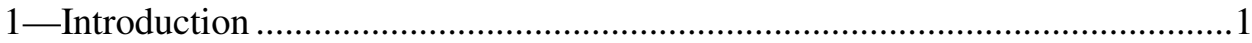

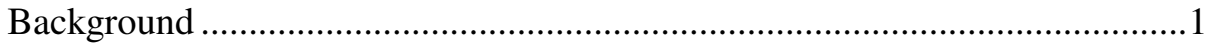

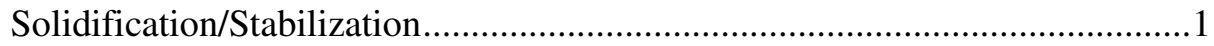

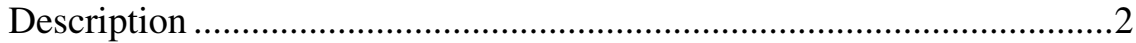

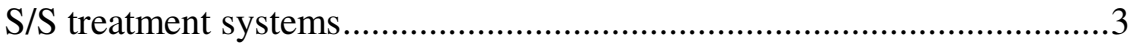

Objective and Scope of Study ....................................................................

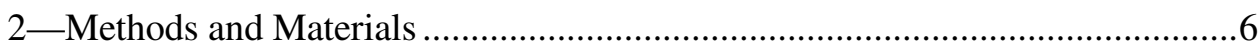

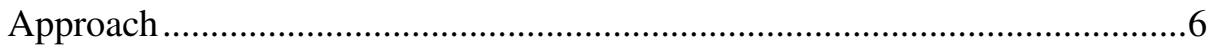

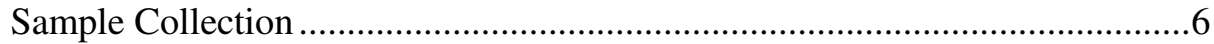

Untreated Sediment Characterization..........................................................

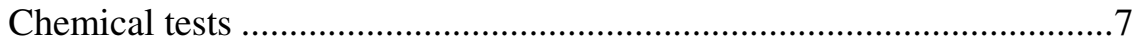

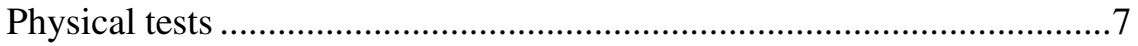

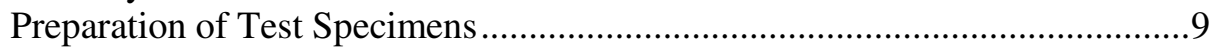

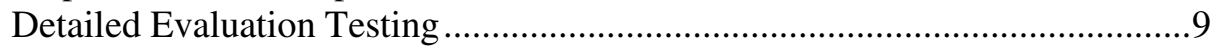

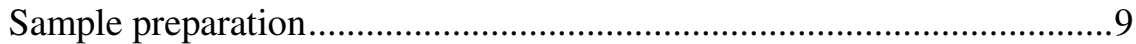

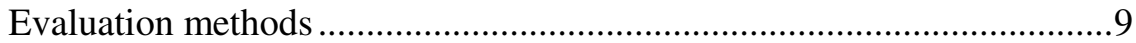

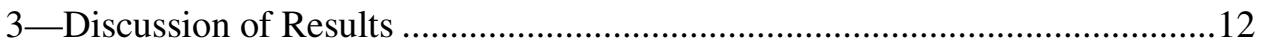

Untreated Sediment Characteristics ..............................................................12

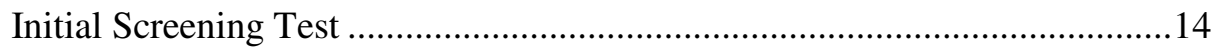

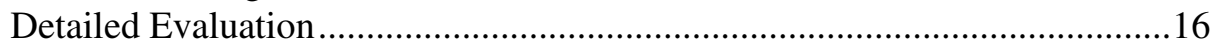

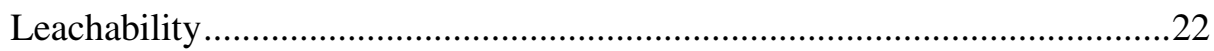

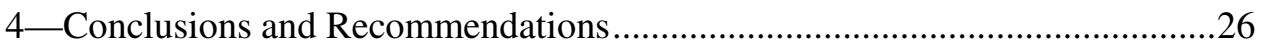

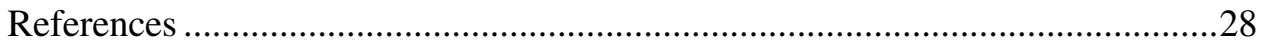

SF 298 


\section{Preface}

The Puget Sound Naval Shipyard performs the repair, overhaul, refurbishment, refueling, and recycling of Navy surface ships and submarines. The Puget Sound Naval Shipyard has grown in size to consist of 344 acres of land, 382 buildings, 6 dry docks, and 9 piers with 12,310 ft of deep-water space.

A CERCLA (Comprehensive Environmental Response, Compensation, and Liabilities Act) cleanup of contaminated marine sediments at the Shipyard is planned to address the human health risks associated with the presence of polychlorinated biphenyls in the surface sediments. Other contaminants of concern include mercury, arsenic, copper, lead, and polyaromatic hydrocarbons. Because the cleanup level has not been determined, the volume of sediments is uncertain, but it is estimated to be in the range of 150,000 to $350,000 \mathrm{cu}$ yd.

This study was performed to determine if solidification/stabilization technologies could be applied to the sediments of the Puget Sound Naval Shipyard to produce a soil-like product that could be of beneficial use. The untreated sediment was evaluated using a variety of tests to determine the characteristics of the material and to determine the leaching potential of the contaminants in the material. Once this was accomplished, a variety of samples were prepared using different binding agents to produce a soil-like material that would decrease the leaching of the contaminants and that had the capacity of being used for daily landfill cover material or other beneficial uses.

This study was prepared for the Naval Facilities Engineering Service Center, Port Hueneme, CA, by the Environmental Laboratory (EL) of the U.S. Army Engineer Research and Development Center (ERDC), Vicksburg, MS. Author of this report was Michael G. Channell, Environmental Processes and Engineering Division (EPED), EL.

This report was prepared under the supervision of Dr. Richard E. Price, Chief, EPED, and Dr. John W. Keeley, Acting Director, EL.

At the time of publication of the report, Dr. James R. Houston was Director of ERDC, and COL James S. Weller, EN, was Commander. 
This report should be cited as follows:

Channell, M. G. (2000). "An evaluation of solidification/stabilization for sediments from the Puget Sound Naval Shipyard," ERDC/EL TR00-9, U.S. Army Engineer Research and Development Center, Vicksburg, MS. 


\section{Conversion Factors, Non-SI to SI Units of Measurement}

Non-SI units of measurement used in this report can be converted to SI units as follows:

\begin{tabular}{|l|l|l||}
\hline Multiply & By & To Obtain \\
\hline \hline acres & $4,046.873$ & square meters \\
\hline cubic yards & 0.7645549 & cubic meters \\
\hline feet & 0.3048 & meters \\
\hline gallons (U.S. liquid) & 0.003785412 & cubic meters \\
\hline inches & 0.0254 & meters \\
\hline pounds (force) per square inch & 0.006894757 & megapascals \\
\hline square inches & 0.00064516 & square meters \\
\hline square yards & 0.8361274 & square meters \\
\hline
\end{tabular}




\section{Introduction}

\section{Background}

First established on Sinclair Inlet in 1891, Puget Sound Naval Station (PSNS) was a desirable location for the one dry dock needed to overhaul America's battleship fleet. From then until the outbreak of World War II, it evolved into the only Pacific Coast Naval Facility able to dry dock the Navy's largest ships.

Puget Sound Naval Shipyard received its current name in 1945 and has grown to 344 acres $^{1}$ of land, 382 buildings, 6 dry docks, one of which is the largest in the Navy, and 9 piers with 12,310 ft of deep-water space.

The Shipyard performs the repair, overhaul, conversion, refurbishment, refueling, decommissioning, dismantling, and recycling of Navy surface ships and submarines. Resources for performing this work include manufacturing, research, development, and testing facilities.

A Comprehensive Environmental Response, Compensation, and Liabilities Act (CERCLA) cleanup of contaminated marine sediments at the Shipyard is planned to address the human health risks associated with the presence of polychlorinated biphenyls (PCBs) in the surface sediments ( 0 to $3 \mathrm{ft}$ ). PCB concentrations in the sediments range up to $80 \mathrm{mg} / \mathrm{kg}$ organic carbon, or $2.6 \mathrm{mg} / \mathrm{kg}$. Other contaminants of concern include mercury, arsenic, copper, lead, and polyaromatic hydrocarbons (PAHs). Because a PCB cleanup level has not yet been determined, the volume of CERCLA sediments is uncertain, but is estimated to be in the range of 150,000 to $350,000 \mathrm{cu}$ yd. Open water disposal is an option for the placement for the dredged material, but upland landfill options are of major importance in the placement of the materials.

\section{Solidification/Stabilization}

Through the Hazardous and Solid Waste Amendments (HSWA) of 1984, and under the Resource Conservation and Recovery Act (RCRA), Congress enacted new responsibilities on the handlers of hazardous waste. In particular, HSWA prohibits the continued land disposal of untreated hazardous waste [(RCRA

\footnotetext{
${ }^{1}$ A table of factors for converting U.S. customary units of measurement to metric (SI) is presented on page vi.
} 
sections 3004 (d)(1), (e)(1), (g)(5), 42 USC 6924 (d)(1), (e)(1), (g)(5)) (U.S. Environmental Protection Agency (USEPA) 1982)].

Of special issue under HSWA is the disposal of liquid waste. Specific language under HSWA bans the future disposal of wastes containing free liquid in landfills. In addition, the utilization of adsorbents to remove free water is prohibited, and specifically stated is that materials used to treat free water must have evidence of a chemical reaction [(RCRA section 3004 (c)(1), USEPA 1982)]. In an effort to address the free liquids prohibition, the USEPA issued the Office of Solid Waste and Emergency Response Policy Directive 9487.00-2A (USEPA 1986a) which stipulates the development of an unconfined compressive strength (UCS) of 50 psi as a measurement of meeting the chemical reaction and free liquid criteria.

Until 1988 the primary goal of solidification/stabilization (S/S) was to meet the spirit of RCRA and to chemically treat free liquids. This goal changed with the development of waste treatment standards applied to the land disposal of waste under the USEPA's Land Disposal Restrictions. Language under RCRA required the USEPA to establish "levels or methods for treatment, if any, which substantially diminish the toxicity of the waste or substantially reduce the likelihood of migration of hazardous constituents from the waste so that short-term and long-term threats to human health and the environment are minimized..." [RCRA sections $3004(\mathrm{~m})(1)$, and 42 USC $6924(\mathrm{~m})(1)$ ]. In an effort to meet this congressional mandate, the USEPA promulgated specific treatment standards over the 1988-1990 time period for listed wastes. These treatment standards were developed under the guidelines of Best Demonstrated Available Technology (BDAT).

$\mathrm{S} / \mathrm{S}$ is one technology that meets the BDAT criteria; thus, it is utilized as one of the primary treatments used to establish treatment standards for metalcontaminated wastes (USEPA 1986b). Much of the experimental work performed for the establishment of these treatment standards, in conjunction with S/S, was conducted at the U.S. Army Engineer Research and Development Center's Waterways Experiment Station (WES) under the direction of the USEPA's Office of Research and Development. The general S/S protocol utilized for treatment standard development is outlined in a report entitled "An Evaluation of Stabilization/Solidification of Fluidized Bed Incinerator Ash (K048 \& KO51)" (Bricka, Holmes, and Cullinane 1988).

\section{Description}

$\mathrm{S} / \mathrm{S}$ is a process that involves the mixing of a contaminated sediment with a binder material to enhance the physical and chemical properties of the sediment and to chemically bind any free liquid (USEPA 1986c). Solidification is generally conceptualized as the enhancement of the physical characteristics of the waste material. This enhancement is accomplished by reducing exposed surface area, which in turn lowers the convective transport of contaminants from the waste. Solidification usually entails the incorporation of the waste into a solid matrix or monolith. In comparison, stabilization involves the reaction of the 
waste's hazardous waste constituents with the S/S reagents to immobilize or otherwise contain them. The stabilization process may be as simple as the addition of lime or a sulfide source to a heavy metal liquid waste, or may involve the development of special reagents specifically formulated to interact with the waste components. Most commercial vendors use a combination of solidification and stabilization to maximize the contaminant immobilization capability of the treated waste.

Several binder systems are currently available and widely used for the S/S of hazardous wastes (Cullinane, Jones, and Malone 1986). Typical binders include Portland cements, pozzolans, and thermoplastics. Most common S/S techniques are designed with either Portland cement or some type of pozzolan as the basic reagent. Portland cement is widely available, relatively economical, and well known to the general public as producing a very durable product. Pozzolans are siliceous materials that, when added to a source of lime, will go through a cementatious process similar to Portland cement but at a much slower rate. Fly ash and blast furnace slags are common pozzolans that are generally considered as waste materials themselves. Kiln dust is also a pozzolan and a waste material. Kiln dust is generated from the production of lime or cement. Although the quality of kiln dust varies, kiln dust generally contains enough lime and fly ash to set simply with the addition of water.

In many cases, the $\mathrm{S} / \mathrm{S}$ process is changed to accommodate specific contaminants and sediment matrices. Generally this is accomplished through the addition of admixtures. Soluble silicates, organophilic clays, activated carbon, as well as a host of other organic and inorganic chemicals, are routinely used as admixtures for the immobilization of contaminants found in the sediment. For hazardous waste containing primarily metal contaminants, generally a cement or pozzolan binder makes up the bulk of the additive. Small quantities of admixture materials are added to the waste/binder mixture for a desired specific effect. Many of the proprietary processes marketed by the vendors of $\mathrm{S} / \mathrm{S}$ are based upon admixtures.

Since it is not possible to consider all feasible modifications to an $\mathrm{S} / \mathrm{S}$ process in this study, investigation of the S/S effectiveness can be narrowed to focus only on generic process types (such as Portland cement or lime/fly ash addition). The performance observed for a specific $\mathrm{S} / \mathrm{S}$ system may vary widely from its generic type, but tailored processes generally are believed to perform better than the generic formulations. Typically there is no need to evaluate proprietary S/S processes or admixtures if generic S/S processes prove to meet the goals of treatment. A comprehensive general discussion of admixtures and proprietary S/S processes is given in Malone and Jones (1979), Malone, Jones, and Larson (1980), and USEPA (1986c).

\section{S/S treatment systems}

Based upon experience, this investigation was performed using four S/S systems using generic binders. Selection of the binders was based on economic 
factors, historical treatment effectiveness, and binder availability. The binders selected for evaluation in this study included:

a. Portland type I cement.

b. Kiln dust.

c. Lime/fly ash.

$d$. Portland type I cement/fly ash.

\section{Objective and Scope of Study}

A feasibility study is currently under development for the CERCLA sediments, with consideration of coordinating the CERCLA remedial action with the disposal action for the unsuitable navigational dredged material. The combined quantity of CERCLA sediments and unsuitable navigational sediments is estimated at 150,000 to $350,000 \mathrm{cu}$ yd.

Several alternatives are being developed for the sediments, ranging in scope from no action to removal and disposal. The alternatives are as follows:

- Alternative 1: No action.

- Alternative 2: Institutional controls, monitored natural attenuation.

- Alternative 3. Enhanced natural recovery.

- Alternative 4. Dredging with confined aquatic disposal.

- Alternative 5. Dredging with near shore contained disposal.

- Alternative 6. Dredging with upland landfill disposal.

- Alternative 7. Dredging, solidification, and upland monofill placement.

The unit costs associated with enhanced natural recovery are approximately $\$ 0.70$ to $\$ 1.00$ per square yard of area. Construction of a confined aquatic disposal or near shore contained disposal facility is estimated to cost $\$ 30$ to $\$ 40$ per cubic yard of sediment. Upland disposal of the sediments in a landfill is estimated to cost $\$ 100$ to $\$ 120$ per cubic yard of sediment transported across the state to a landfill in eastern Washington.

The general objectives of this S/S investigation are to evaluate Alternative 7 and to evaluate S/S for application to sediment collected from the PSNS site. The specific objectives of this study are summarized as follows: 
a. Determine if $\mathrm{S} / \mathrm{S}$ techniques can be applied to contaminated sediments to reduce contaminant leaching to render the sediments acceptable for upland disposal or beneficial use.

$b$. Evaluate the physical properties of the solidified/stabilized sediments to determine if $\mathrm{S} / \mathrm{S}$ techniques will substantially improve the physical handling properties of the sediment. This evaluation will provide baseline data for the comparison of the untreated sediment to the sediment treated using $\mathrm{S} / \mathrm{S}$ techniques. 


\section{Methods and Materials}

\section{Approach}

This investigation was conducted in four primary phases:

a. Phase I: Sample Collection. Sediments were collected from the PSNS and shipped to WES. Samples were packed in coolers and iced down to prevent the loss of organic contaminants from the sample.

b. Phase II. Preliminary Testing. Tests were performed to determine the appropriate amount of binder and water to be added to the sediment for the detailed evaluation. Physical tests were performed on the samples to evaluate strength development for each mixture.

c. Phase III. Detailed Evaluation. Based on the information from preliminary testing, samples were prepared for detailed evaluation. Physical tests and contaminant leach tests were performed on the samples to evaluate the effectiveness of S/S on the sediment and contaminant leachability.

d. Phase IV: Data Analysis and Report Preparation. Test data were consolidated and evaluated.

\section{Sample Collection}

The materials of interest were contaminated sediments collected from the PSNS. The sediments were collected from three sites: the CAD, the East, and the West sites. (The "CAD site" is a locally known site at the PSNS.) The East site was located off the south end of Pier 3, and the West site was located approximately $100 \mathrm{ft}$ east of Mooring G. These three sampling sites were chosen based on previous sampling that was performed at the PSNS in 1994. The samples were packed in ice chests and shipped to WES for the treatment study.

Upon receipt of the samples at WES, they were inventoried and stored in walk-in coolers until needed for testing. 


\section{Untreated Sediment Characterization}

\section{Chemical tests}

Bulk analysis. Analysis of the untreated sediments from the CAD, East, and West sites was performed to determine the metal, PCB, and PAH contaminant concentrations present in each sample. Once the analysis of the three sites was completed, the sediments were consolidated into one sample. The samples were placed in a 55-gal drum and homogenized using a lightin mixer.

Toxicity characteristic leaching procedure (TCLP). The untreated sediment was subjected to the TCLP extraction procedure to determine the hazardous characteristics of the sediment and to measure the contaminant mobility as defined by the USEPA (USEPA 1986a). This method consisted of crushing the sample to pass a 9.5-mm standard sieve. Since the sample had such high moisture content, the sample was simply passed through a $9.5-\mathrm{mm}$ sieve to remove any large debris from the sample. The sample was placed in a $0.5 \mathrm{~N}$ acetic acid extract or an acetate buffer extract, depending on the buffering capacity of the sediment, at a 20:1 liquid-to-solids ratio. The sediment and extract were placed in 1-gal glass jars and tumbled end over end for $18 \mathrm{hr}$. At the completion of this period, the sample was filtered using a Whatman GF/F $0.75-\mu \mathrm{m}$ filter. Only a single extraction was performed for the test. The filtered extracts were placed in precleaned bottles and stored at $4{ }^{\circ} \mathrm{C}$ prior to analysis. Each extract for the sediment was analyzed for the contaminants of concern for that sediment.

\section{Physical tests}

Physical characteristics of the untreated sediment were evaluated using the following test procedures. Test specimens were prepared in accordance with the requirements of the test method discussed below.

Moisture content. The moisture content for all of the sediment, initial screen test (IST), and detailed evaluation (DE) samples was conducted according to modified ASTM D-2216 ((American Society for Testing and Materials (ASTM) 1992a). This method was modified by drying the sample to constant weight at $60{ }^{\circ} \mathrm{C}$. Lower temperatures are utilized with contaminated materials to avoid removing large volumes of the contaminants and to reduce the release of hydrated water from the sample. The moisture content measurements were used to calculate the dry weight of each sample.

Resistance to penetration. The Cone Index (CI) determination was performed for the sediment and was conducted according to TM 5-530 (Headquarters, Department of the Army (HQDA) 1971). The CI measures the resistance of a material to the penetration of a $30-$ deg right circular cone. The CI value is reported as force per unit surface area (pounds per square inch) of the cone base required to push the cone through a test material at a rate of $72 \mathrm{in.} / \mathrm{min}$. Two cones are available for this test: (1) the standard WES cone having an area of $0.5 \mathrm{sq}$ in., and (2) the airfield penetrometer having a base area of $0.2 \mathrm{sq}$ in. Because of its smaller cone, the airfield penetrometer can measure larger CI values. 
It was convenient to use the standard WES cone penetrometer on materials with a CI up to 300 psi. The maximum CI value that can be measured by the airfield penetrometer is $750 \mathrm{psi}$; therefore, materials having CI values greater than 750 psi are reported simply as $>750$ psi.

Bulk density. The bulk density of the soil composite will be measured according to the American Society of Agronomy 13 (ASA 1965). This density represents the uncompacted laboratory density of the soil samples as they are used in the S/S treatability studies. The laboratory bulk density is not the in situ density, which is measured in the field. The bulk density of the untreated soil will be used as a comparison to the solidified/stabilized soil for calculating percent volume increase of the solidified soil. The tests will be conducted by loosely placing a known mass of soil into a mold of known volume; densities will be calculated using the mass/volume data and will be reported in units of pounds per cubic foot. A single bulk density will be performed on each subsample (Replicates A, B, and C) of the soil.

Grain-size analysis and Atterberg limits. Grain-size distribution of each replicate of the soil will be determined in accordance with ASTM Method D-422 (Particle Size Analysis of Soils) (ASTM 1992b). Curves reflecting particle distribution as a function of grain size will be prepared. The Atterberg limits of the unstabilized soil will be determined in accordance with ASTM D-4318 (ASTM 1992b). The test will determine the water content of the soil between the plastic and liquid state. The plastic limit is the water content at which the soil will start to crumble when rolled into a 3-mm thread under the palm of the hand. The liquid limit is defined as the lowest water content at which the soil will flow as a viscous liquid.

Proctor density. The optimum moisture content for maximum dry density (proctor density) will be determined for each replicate of the soil using ASTM Method D 698 (ASTM 1990). Curves will be developed to display the relationship between maximum dry density and moisture content. All density values will be reported in units of pounds per cubic foot. A single proctor density test will be performed on each subsample (Replicates A, B, and C) for the soil.

Compressive strength. If the soil is cohesive enough to permit strength testing, the unconfined compressive strength (UCS) of the soil will be measured using ASTM Method C 109 (ASTM 1990). The soil will be compacted to 85 percent standard proctor density for UCS testing. If the sample crumbles upon removal from the mold, the test will not be conducted. All UCS measurements will be in triplicate, and the results will be reported in pounds per square inch. UCS of the untreated soil will be used for comparison to the UCS for the treated soil. Triplicate UCS will be performed on each replicate of the soil.

Specific gravity. Specific gravity will be evaluated in accordance with ASTM D 854 (ASTM 1990). A single specific gravity test will be performed on each replicate for the soil. 


\section{Preparation of Test Specimens}

Four processes were used to solidify/stabilize the sediment from the PSNS material and were differentiated by the type of binder material used in the process. The four processes used for this study were Portland cement, kiln dust, lime with class F fly ash, and Portland cement with class F fly ash.

WES prepared generic chemical S/S formulations for four binder systems (cement, kiln dust, lime/fly ash, and Portland cement/fly ash). An IST was used to narrow the range of binder-to-sediment ratios (BSRs) and evaluate the waterto-sediment ratios (WSRs) necessary for detailed S/S treatment of the PSNS sediment. None of the sediment required the addition of water to the sediment to ensure the hydration of the binder material. The IST involved mixing binder and sediment in a K455S Hobart mixer.

After each formulation was mixed for $10 \mathrm{~min}$, the mixture was placed in 4-in.-diam by 4-in.-high cylindrical molds. The samples were placed in an environmental chamber that controlled the temperature at $23{ }^{\circ} \mathrm{C}$ and 98 percent relative humidity and allowed to cure until needed for testing.

Determination of the optimal BSRs was based on the results of the CI test performed on the IST samples during a 48-hr curing period. CI measurement, as described in sediment characterization, was performed on these samples at 2, 4, 8,24 , and $48 \mathrm{hr}$ after curing.

\section{Detailed Evaluation Testing}

\section{Sample preparation}

Various formulations of cement, kiln dust, lime/fly ash, and cement/fly ash were prepared for the sediment for the detailed S/S evaluations. Solidified/ stabilized specimens were prepared by mixing the binder with the contaminated sediment in a Hobart C-600 mixer. The sediment and additives were mixed for $5 \mathrm{~min}$, the sides of the container were scraped to remove adhering material, and the mixture was mixed an additional $5 \mathrm{~min}$. Mixtures were then poured into molds and allowed to cure in environmental chambers. The molded solidified/ stabilized materials were cured in the molds a minimum of $24 \mathrm{hr}$.

\section{Evaluation methods}

The success of an $\mathrm{S} / \mathrm{S}$ process can be evaluated in a number of ways. For this study, the CI, pH of the treated material, UCS, and TCLP of the treated material were used to evaluate the success of the samples.

Set time. The set time is defined as the time required to develop sufficient rigidity following mixing to resist the penetration of a standard rod or needle.

Set time will be evaluated using the CI. Measurements will be made at 2, 4, 8, 
24, and $48 \mathrm{hr}$. CI tests will be performed in triplicate for each formulation (Replicates $\mathrm{A}, \mathrm{B}$, and $\mathrm{C}$ ) for each binder.

Bleed water. Bleed water is defined as the water that comes to the surface of an S/S mixture because of gravitational settling of the soil and cement particles in the mix. The amount of bleed water produced in each formulation selected for detailed evaluation will be measured using ASTM Method C 232 (Bleeding of Concrete) (ASTM 1992a). The method may be modified to use a smaller sample size. Because of limited sample sizes, insufficient bleed water may be generated to accurately perform ASTM C 232. In such cases, a qualitative evaluation of bleed water development will be conducted.

Workability. The workability of a mixture is similar to mix consistency. It is a measure of such factors as viscosity, plasticity, density, and water content. A workable mix has the desired properties of mixability and flowability. One measure of workability, or consistency, is slump. ASTM Method C 143 (Slump of Portland Cement Concrete) (ASTM 1992a) will be used to measure the slump of the test mixture. This method may be modified to reduce the volume of soil required for testing. A single slump test will be performed on each formulation (Replicates A, B, and C) for each binder formulation.

Compressive strength. The UCS of both solidified/stabilized soil composites will be determined using ASTM Method C 109 (ASTM 1992b). Sample molds are 2-in. cubes. UCS will be measured at a cure times of 7, 14, 21, and 28 days. A UCS test will be performed on each formulation (Replicates A, B, and $\mathrm{C}$ ) for each binder formulation. The results will be reported in pounds per square inch. UCS data indicate the suitability of the S/S material for construction or fill.

Density/bulking. The densities of the final mix formulations and the volume increases associated with the addition of the $\mathrm{S} / \mathrm{S}$ agents and water will be measured following the procedures in Method 13 of ASA (1965). Density values will be reported in units of pounds per cubic foot. Estimates of the percentage volume increases caused by $\mathrm{S} / \mathrm{S}$ will be based on comparisons of mass of contaminated soil per unit volume in the untreated soil and the mass of contaminated soil per unit volume in the $\mathrm{S} / \mathrm{S}$ soil. Estimates of bulking will be calculated as the ratio of the corrected density of the S/S soil with the in situ density, as measured in the field; the bulk density, as measured using ASA Method 13; and 85 percent of the maximum proctor density. A single density will be performed on each formulation (Replicates A, B, and C) for each binder formulation.

Specific gravity. Specific gravity will be evaluated in accordance with ASTM D 854 (ASTM 1992b).

Moisture content evaluations. Moisture content evaluations will be conducted in triplicate on each formulation (Replicates A, B, and C) for each binder according to ASTM D 2216 (ASTM 1992a).

Paint filter test. A single subsample from each replicate (A, B, and C) for each soil will be subjected to the paint filter test. 
Toxicity characteristic leaching procedure. TCLP extractions will be performed on the solidified/stabilized samples after a determination of the optimal BSR has been performed. Samples will be prepared for the most contaminated heavy metal sediment with the optimal formulation and allowed to cure for $24 \mathrm{hr}$. The TCLP extracts will be analyzed for the contaminants of concern for each mixture. The TCLP will be performed according to the test method previously described in the chemical tests for the untreated sediment characterization section.

Sequential batch leach test (SBLT). The solidified material for the detailed evaluation will be subjected to the SBLT leach test. This test is utilized to determine the amount of contaminant that is mobile under equilibrium extraction conditions. The SBLT procedure outlined by Myers and Zappi (1989) was followed for this study.

The SBLT test method crushes the sample so that it passes a 9.5-mm standard sieve. Moisture content is performed on the sample to determine the amount of water present in the sample. For the first cycle of the extraction, the sample is weighed out and placed in an extraction vessel. A liquid-to-solids ratio of 4:1 is used for the SBLT test. The amount of water added to the sample is calculated by multiplying the weight of the sample by 4 and subtracting the moisture already present in the sample. Distilled deionized water is used as the extraction fluid for the test. After the sample and the water are placed in the extraction vessel, the sample is tumbled end over end for $24 \mathrm{hr}$. At the completion of the tumbling, the sample is filtered using a Millipore Type HA $0.45-\mu \mathrm{m}$ filter. The filtrate is placed in precleaned bottles and stored at $4{ }^{\circ} \mathrm{C}$ until all extraction cycles are completed. The filter paper is placed back in the extraction vessel, and water is added to the sample and tumbled for $24 \mathrm{hr}$. Five cycles were completed during this study. 


\section{Discussion of Results}

\section{Untreated Sediment Characteristics}

Three sets of samples were collected for the evaluation of S/S for the sediment from the PSNS. Eight samples were collected from the CAD site, four samples east of Mooring $\mathrm{G}$ were labeled as West samples, and four samples were collected off the south end of Pier 3 and labeled as East samples. Initial contaminant concentrations for metals, PAHs, and PCBs were measured from each site to determine if the samples were representative of previous sampling performed in the area in 1993 and 1994 (Greiner Inc. 1999). Once these concentrations of metals, PAHs, and PCBs were obtained and compared to the previous sampling, the samples were consolidated and mixed to form one sample for the study. The results of the contaminant concentrations for the untreated sediment are presented in Table 1. The previous samplings performed in 1993 and 1994 are also presented in Table 1 for comparison. It should be noted that the concentrations for the sampling performed previously were calculated based on the total organic carbon (TOC) in the sample. The samples analyzed by the WES Chemistry Branch were calculated based on the total dry weight of the samples. The TOC for both sets of samples ranged between 3 and 4 percent of the sample. $\mathrm{PCB}$ s were not detected in any of the samples collected for the S/S study.

Table 2 presents the data for the physical tests performed on the untreated sediment. The sample was extremely wet; therefore, the permeability test could not be performed on the sample. The UCS and CI samples were prepared by drying the sample and then adding water back to the sample at $85 \%$ of the optimal water content. These samples were not cohesive, and most of the samples crumbled when trying to remove them from the molds. The bulk density was measured on the sediment as received at approximately $69 \%$ moisture content. All samples failed the paint filter test (water passed through the paint filter). This is an important fact that shows that the material cannot be placed directly into an upland landfill environment. The material would have to be placed in a dewatering facility and "dried" before the material could be placed in a landfill. This will substantially increase the cost of handling the material and prolong the cleanup effort for the site. 


\section{Table 1}

Results of Bulk Chemistry for Untreated PSNS Sediment

\begin{tabular}{|c|c|c|c|c|c|c|}
\hline Analyte & CAD site & Site $214^{1}$ & West site & Site $452^{1}$ & East site & Site $132^{1}$ \\
\hline \multicolumn{7}{|c|}{ Metals, $\mathbf{m g} / \mathbf{k g}$} \\
\hline Arsenic & 26.5 & 24.8 & 21.4 & 16.2 & 16.7 & 95.4 \\
\hline Cadmium & 2.2 & $1 U$ & 2.5 & 2.8 & 1.6 & 5.4 \\
\hline Chromium & 113 & $80.7 \mathrm{~J}$ & 88 & 70.2 & 57 & 98.3 \\
\hline Copper & 793 & 601 & 527 & 269 & 179 & 1700 \\
\hline Lead & 306 & 582 & 220 & 155 & 88.2 & 581 \\
\hline Mercury & & $1.7 \mathrm{~J}$ & & $1.2 \mathrm{~J}$ & & 1.2 \\
\hline Silver & $<5$ & $1.6 \mathrm{U}$ & 2.2 & $5.5 \mathrm{U}$ & $<1.0$ & $0.67 \mathrm{UJ}$ \\
\hline Zinc & 1070 & 1510 & 471 & 294 & 268 & 1230 \\
\hline \multicolumn{7}{|c|}{ PAHs, $\mu \mathrm{g} / \mathrm{kg}$} \\
\hline Napthalene & $<425$ & 56.75 & $120 \mathrm{~J}$ & 42 & $<510$ & 4566 \\
\hline Acenaphthylyene & $<425$ & 22.1 & $<480$ & 436 & $<510$ & 4566 \\
\hline Acenaphthene & $<425$ & 61.97 & $<480$ & 436 & $<510$ & 4566 \\
\hline Fluorene & $<425$ & 66.96 & $<480$ & 18.1 & $<510$ & 4566 \\
\hline Phenanthrene & $290 \mathrm{~J}$ & 619.7 & $360 \mathrm{~J}$ & 196 & $220 \mathrm{~J}$ & 1033 \\
\hline Anthracene & $80 \mathrm{~J}$ & 103.2 & $90 \mathrm{~J}$ & 39.4 & $90 \mathrm{~J}$ & 4566 \\
\hline Fluoranthene & 462 & 619.7 & 569 & 316 & $490 \mathrm{~J}$ & 2000 \\
\hline Pyrene & 833 & 619.7 & 1080 & 420 & 892 & 2223 \\
\hline Chrysene & $360 \mathrm{~J}$ & 442.6 & $450 \mathrm{~J}$ & 241 & $460 \mathrm{~J}$ & 1223 \\
\hline Benzo(a)Anthracene & $260 \mathrm{~J}$ & 345 & $300 \mathrm{~J}$ & 241 & $280 \mathrm{~J}$ & 690 \\
\hline Benzo(a)Pyrene & $270 \mathrm{~J}$ & 315.5 & $320 \mathrm{~J}$ & 211 & $240 \mathrm{~J}$ & 756 \\
\hline Methylnaphthalene & $<425$ & 50.6 & $150 \mathrm{~J}$ & 16.6 & $<510$ & 4566 \\
\hline
\end{tabular}




\section{Table 2 \\ Physical Test Results of Untreated Sediment}

\begin{tabular}{||l|l|l|l||}
\hline \hline Physical test & Replicate 1 & Replicate 2 & Replicate $\mathbf{3}^{\mathbf{1}}$ \\
\hline \hline Moisture content, \% & 68.44 & 70.43 & 70.13 \\
\hline $\begin{array}{l}\text { Proctor density/optimal } \\
\text { water content, \% }\end{array}$ & 25 & 27 & 29 \\
\hline UCS & No sample & No sample & No sample \\
\hline Specific gravity & 2.8 & 2.8 & 2.7 \\
\hline Bulk density, pcf & 80.1 & 85.4 & 81.7 \\
\hline Cl, psi & 5 & No sample & 5 \\
\hline Paint filter & Failed & Failed & Failed \\
\hline Permeability & No sample & No sample & No sample \\
\hline \hline 1 Combination of samples from the three sites. & & \\
\hline
\end{tabular}

\section{Initial Screening Test}

The IST portion of the study was performed to evaluate the potential of S/S to produce a product that had soil-like characteristics and to narrow the range of binder-to-sediment ratios (BSRs). Three ratios of Portland cement, kiln dust, and lime/fly ash were used to solidify/stabilize the sample. Initially, five BSRs were evaluated for cement and kiln dust: $0.15,0.2,0.25,0.3$, and 0.6. The BSRs were calculated as a percentage of the total weight of the sediment. Two ratios for the lime/fly ash binders were evaluated for the IST portion of the study. These ratios were $0.1 / 0.1$ and $0.2 / 0.2$. These samples were prepared by adding the binder as a dry material to the sediment.

Figure 1 presents the results of the CI for the IST portion of the study that were treated with the cement binder. The data show that during the cure time of $48 \mathrm{hr}$, two of the samples achieved the maximum CI value of $750 \mathrm{psi}$. These two samples were treated with 30 and $60 \%$ cement binder ratio. The $25 \%$ cement ratio achieved a CI of approximately $650 \mathrm{psi}$ at the end of $48 \mathrm{hr}$ of cure. The 15 and $20 \%$ cement ratios achieved $48 \mathrm{hr}$ CI readings of 365 and 475 psi, respectively. All of the samples were slow to achieve strength except for the $60 \%$ BSR. This is due to the fact that excess water was in the sediment sample. The $60 \%$ sample quickly hydrated the water present in the sediment and set up at a faster rate of speed. Since one of the main goals of the study was to develop a material that had soil-like properties, the 25,30 , and $60 \%$ samples gained too much strength to meet these criteria. 


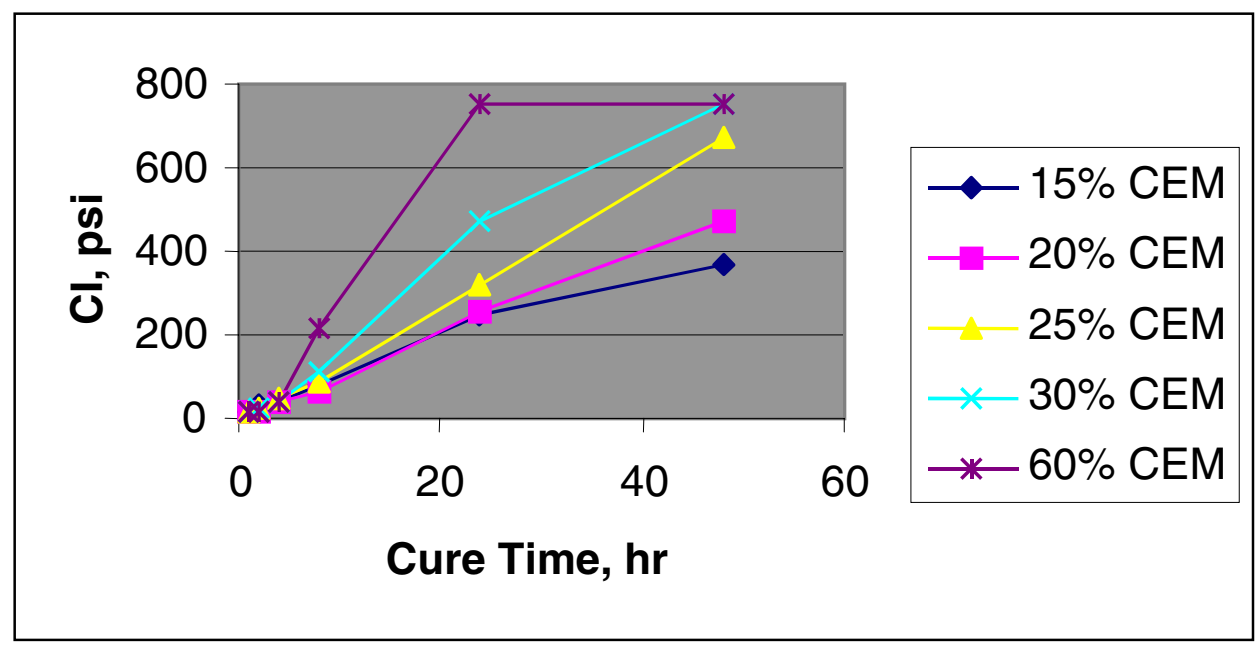

Figure 1. IST Cl results for the cement binder (CEM)

Figure 2 presents the data for the CI for the kiln dust samples prepared for the IST portion of the study. Kiln dust, when used as a binding agent, generally does not gain the strength that Portland cement does. This is true for the samples treated with the kiln dust for the IST portion of the study. None of the samples evaluated gained much strength until after $24 \mathrm{hr}$ of cure time had elapsed. Between 24 and $48 \mathrm{hr}$, the samples started to quickly gain strength, although not to the extent of the cement samples. The 30 and $60 \%$ kiln dust samples had the highest strength after $48 \mathrm{hr}$ of cure with a CI reading of $120 \mathrm{psi}$. All of the samples showed a gain in strength so that they would produce a soil-like material.

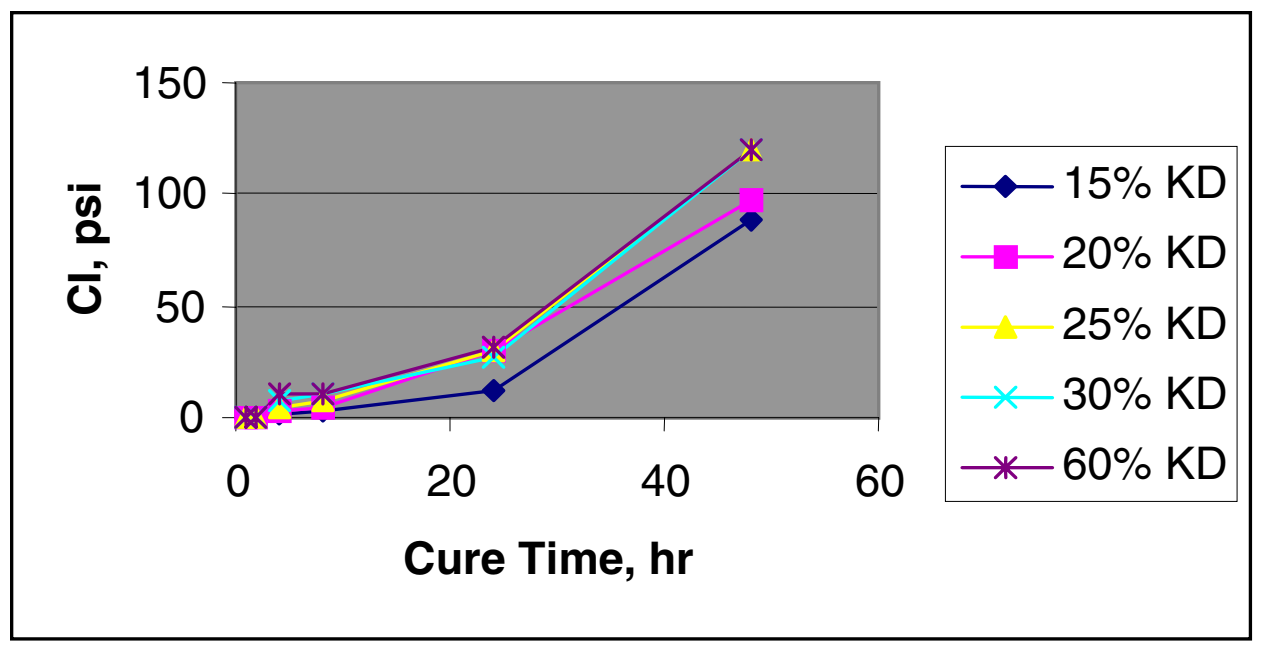

Figure 2. IST $\mathrm{Cl}$ results for the kiln dust binder (KD) 
Figure 3 presents the CI data for the lime/fly ash samples for the IST portion of the study. Only two BSRs were chosen for the IST to determine a range for the BSRs to be used in the detailed evaluation portion of the study. The $20 \% / 20 \%$ lime/fly ash samples achieved the highest CI after $48 \mathrm{hr}$ with a reading of 125 psi. The 10\%/10\% lime/fly ash sample achieved a CI of 90 psi after $48 \mathrm{hr}$ of cure. The 20\%/20\% BSR gained strength throughout the cure time of $48 \mathrm{hr}$ while the $10 \% / 10 \%$ sample stayed relatively unchanged until after $8 \mathrm{hr}$ of cure. Both samples produced a material that would be soil-like in nature.

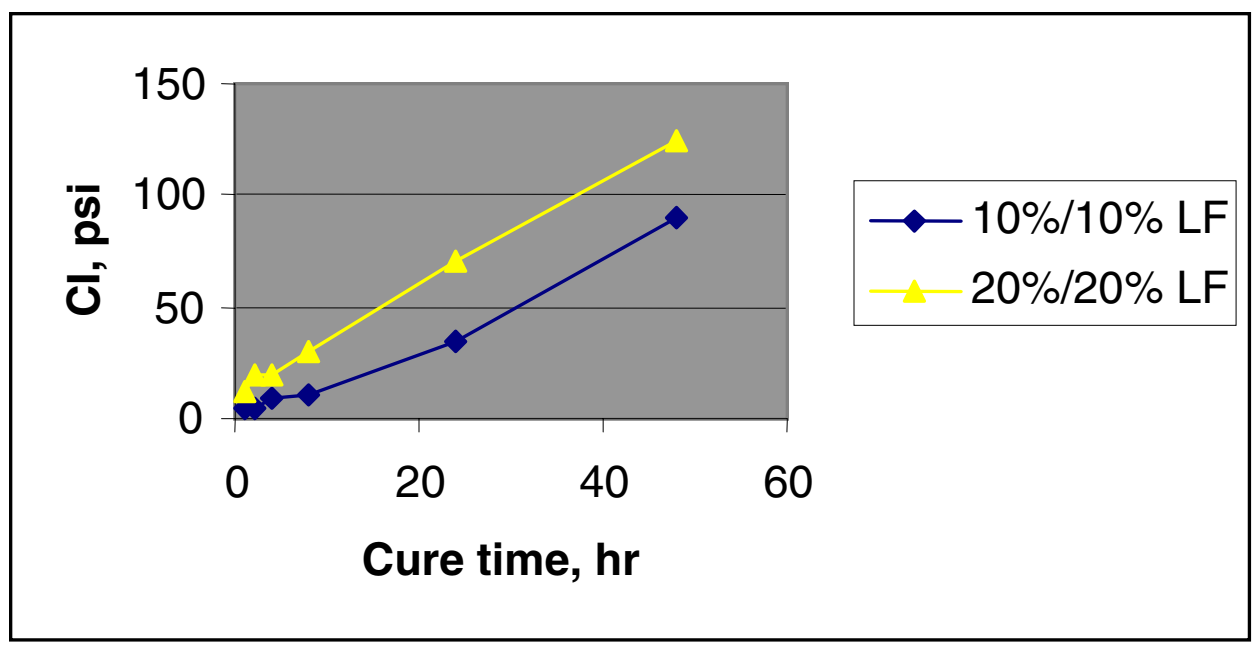

Figure 3. IST Cl results for lime/fly ash binder (LF)

\section{Detailed Evaluation}

Samples were prepared for the detailed evaluation portion of the study using the binders that were evaluated during the IST portion of the study. Based on the results from the IST, four ratios of each binder were used for the preparation of the detailed evaluation samples. Figure 4 presents the results of the CI for the cement samples prepared for the detailed evaluation. The samples prepared with the $9 \%$ and $12 \%$ cement BSRs gained the maximum strength for the CI after $48 \mathrm{hr}$ of cure. The $3 \% \mathrm{BSR}$ did not gain any strength during the cure time due to the fact that there was excessive water in the sample. Water was present on the top of the samples, thus indicating that the mixture would fail the paint filter test even after $48 \mathrm{hr}$ of cure. The $6 \%$ BSR performed the best for the BSRs evaluated for CI. The $6 \%$ sample achieved a CI of 265 psi after $48 \mathrm{hr}$ of cure, which produced a material that was soil-like in nature and very workable.

Figure 5 presents the data for the CI for the kiln dust BSRs evaluated during the detailed evaluation portion of the study. As seen in Figure 5, none of the samples developed much strength during the 48-hr cure time. The $25 \%$ kiln dust sample developed the highest CI of 40 psi, but it was noted that this sample was still extremely wet after the cure time had elapsed. All of the samples evaluated had water present on the top of the sample after $8 \mathrm{hr}$ of cure. None of the 


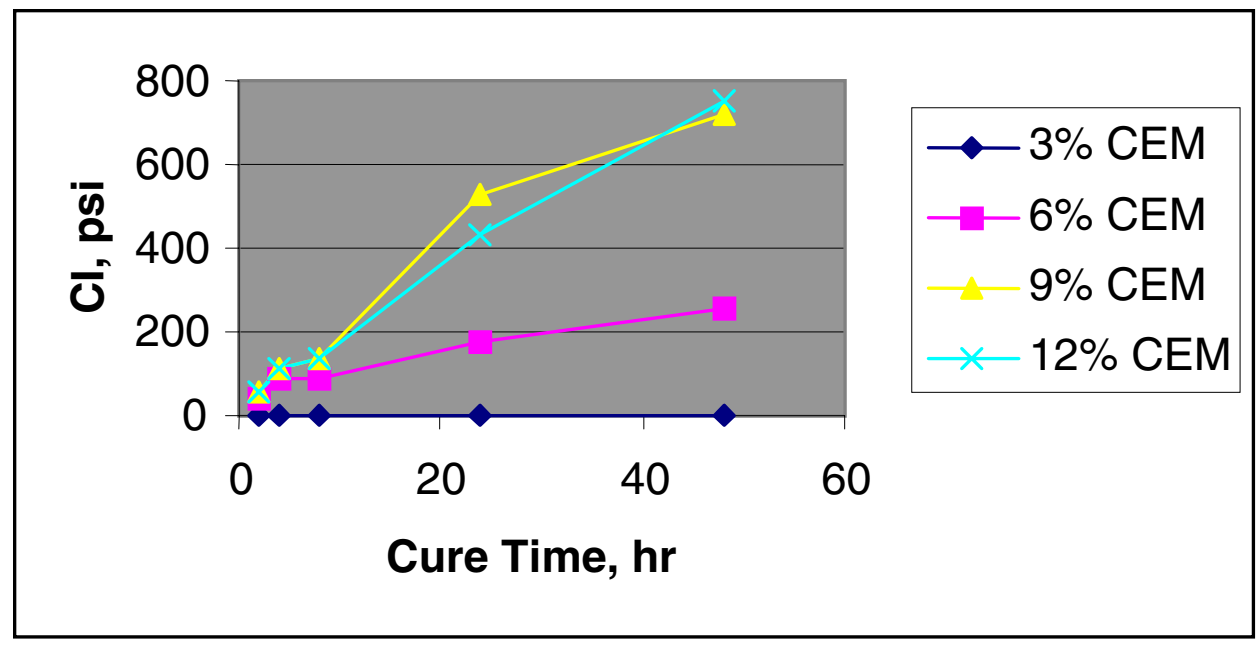

Figure 4. $\mathrm{Cl}$ results for cement BSRs

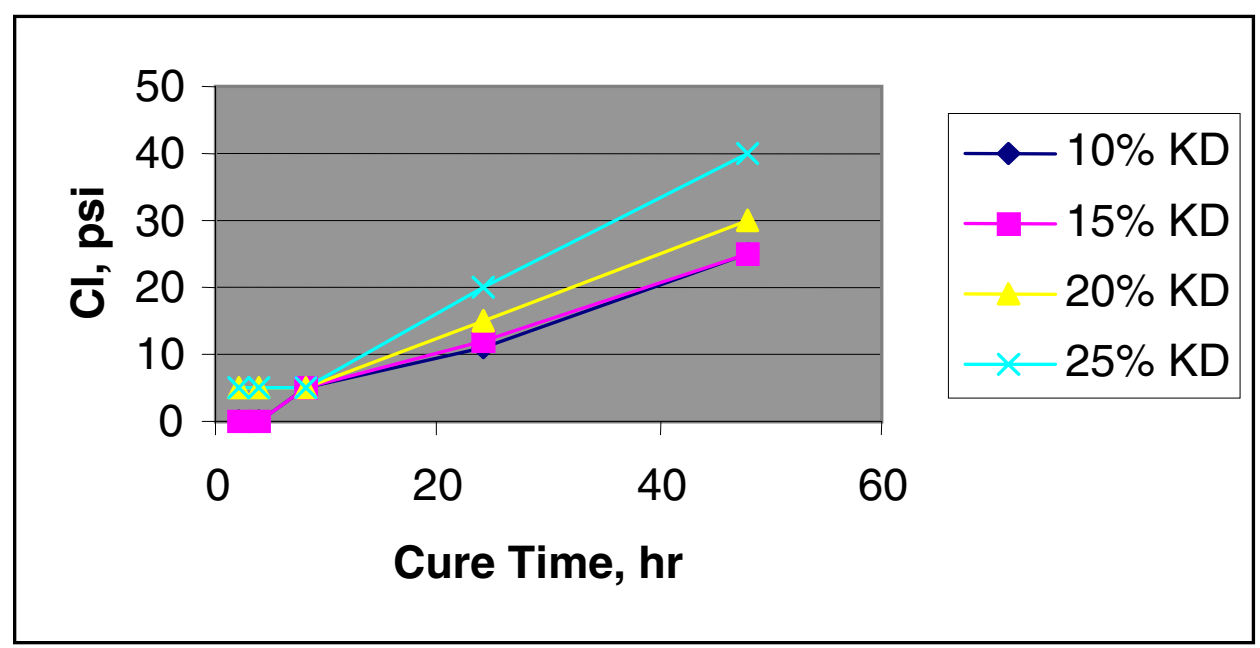

Figure 5. $\quad \mathrm{Cl}$ results for kiln dust BSRs

samples were soil-like in nature after $48 \mathrm{hr}$ of cure. It should be noted that as the 28-day cure time progressed, much of the water that formed on the samples dissipated, and the samples did indicate strength development.

Figure 6 presents the CI for the lime/fly ash samples evaluated. The lime/fly ash samples performed in the same manner as the samples treated with the kiln dust. The higher ratios of the binder developed more strength during the 48-hr cure time, but the strength was still too low to be considered a soil-like material. It was noted that water was present on all of the samples at $8 \mathrm{hr}$ of cure except for the 10\%/10\% BSR. As with the kiln dust samples, during the 28-day cure time, the water dissipated from the sample. 


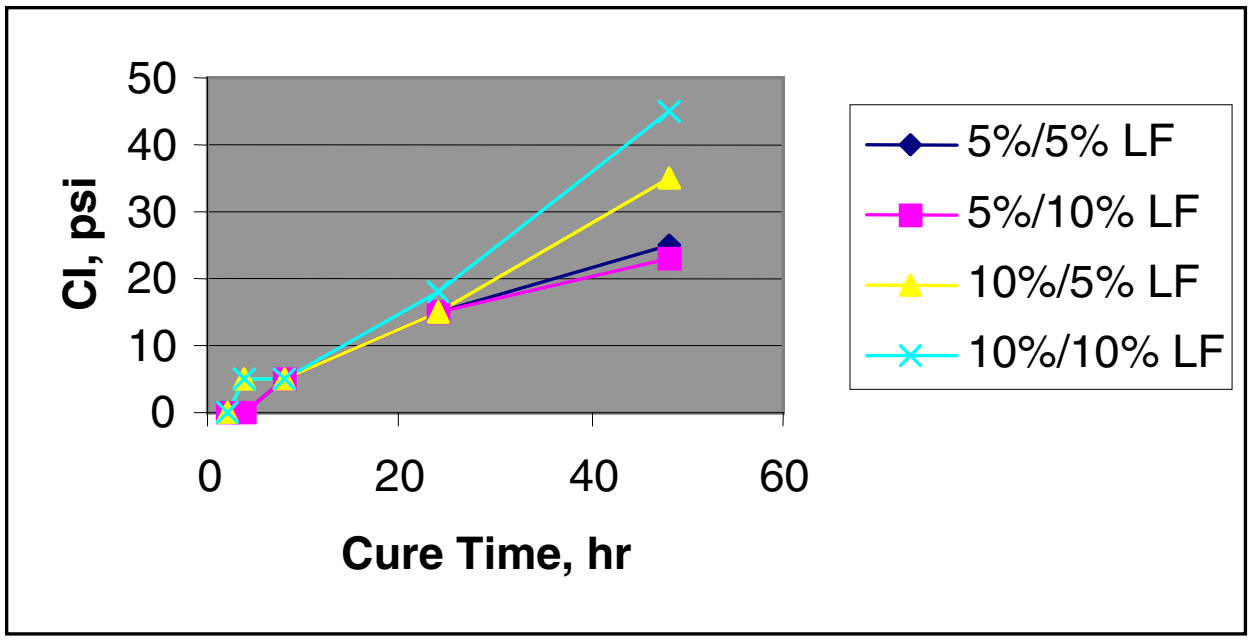

Figure 6. $\quad \mathrm{Cl}$ results for lime/fly ash BSRs

Figure 7 presents the data for the UCS for the samples prepared using the cement binder. The majority of the samples evaluated did not form good samples for UCS testing. Large voids were present in many of the samples, which lowered the UCS for the sample. Still, with deficiencies in the samples, all of the samples except the 3\% BSR produced strengths that indicated soil-like properties. The $3 \%$ cement sample did not gain any strength during the 28-day cure time. This sample was extremely wet and did not have enough binder to hydrate the water present in the sample. The $6 \%$ cement sample performed well and gained strength during the cure time. The $9 \%$ sample decreased in strength during the cure time, while the $12 \%$ percent sample started to decrease in strength toward the end of the UCS evaluation. Overall, the $6 \%$ cement sample performed the best for the cement BSR, but this sample had a high moisture content at the end of the 28-day cure time.

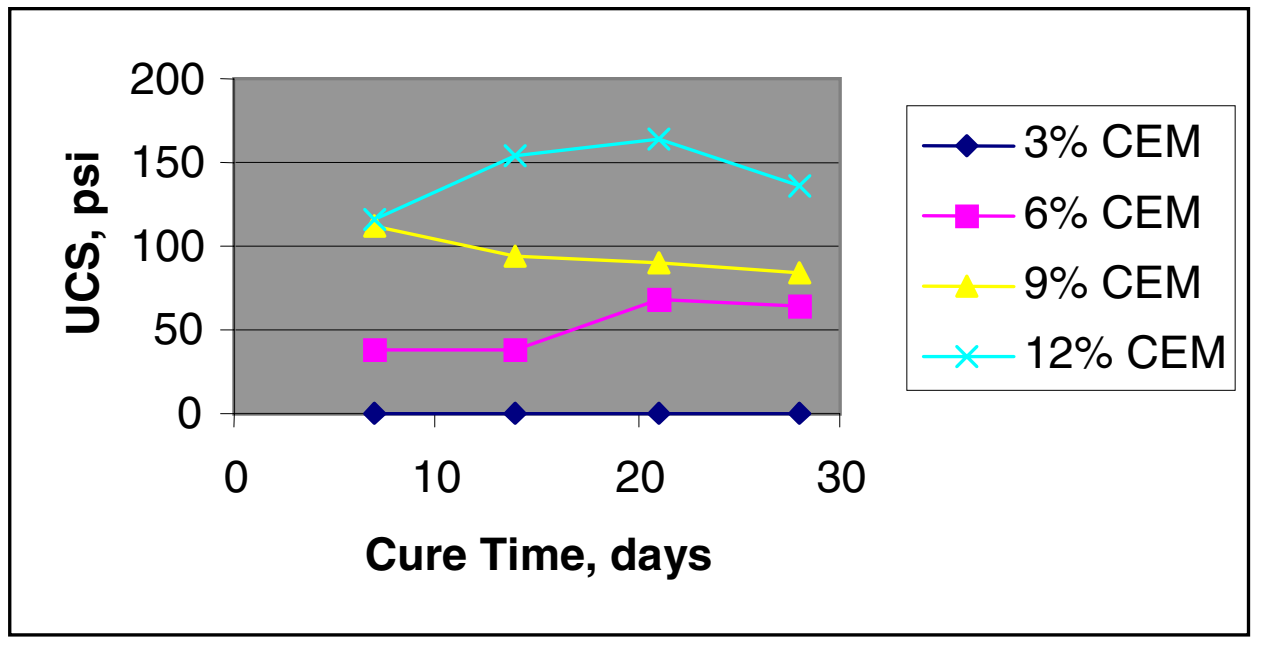

Figure 7. UCS results for the cement BSRs 
Figure 8 presents the UCS data for the kiln dust BSR. The data from the kiln dust samples show that all of the samples evaluated gained strength during the 28-day cure time. As expected, the higher BSRs of kiln dust gained the most strength during the evaluation, while the lowest BSR of $10 \%$ did not gain above 70 psi during the test. The $15 \%$ kiln dust BSR showed the quickest gain in strength, reaching almost 100 psi after 7 days of cure. The $25 \%$ kiln dust BSR gained the most strength during the 28 days, achieving a UCS of 145 psi after the total cure time. The three ratios of 15,20 , and $25 \%$ all produced materials that were soil-like in nature and could be easily handled.

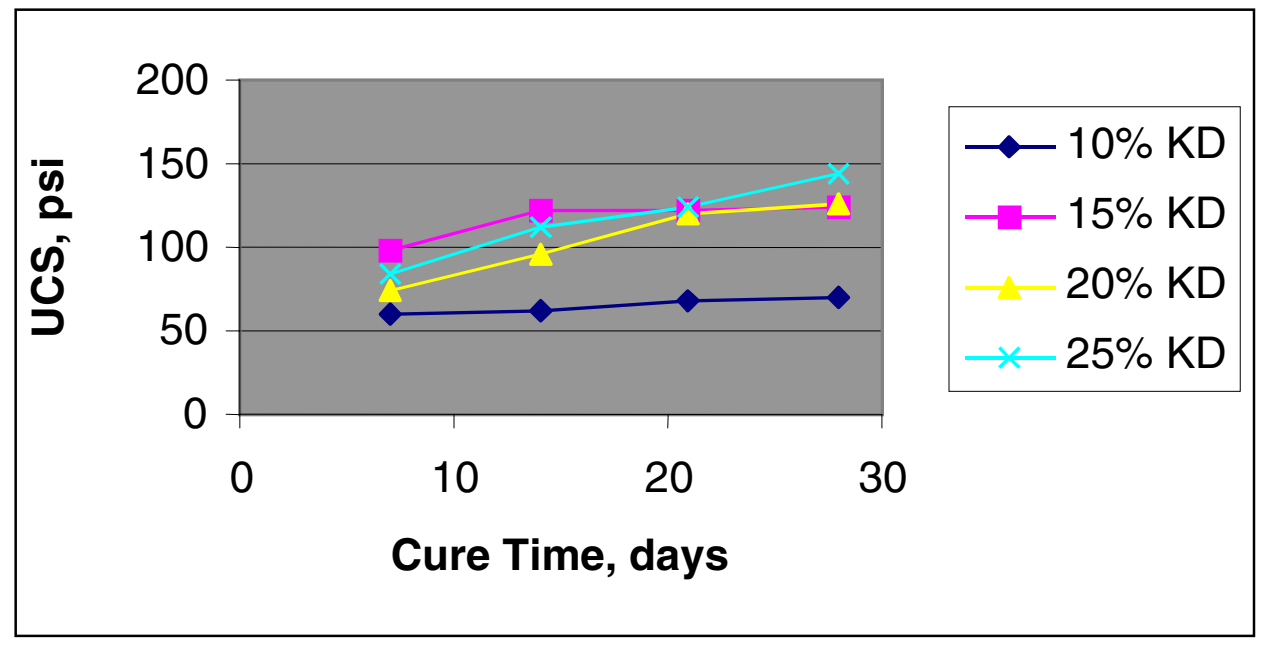

Figure 8. UCS results for the kiln dust BSRs

Figure 9 presents the data for the UCS testing of the sediment treated with the lime/fly ash binder. As with the kiln dust samples, all of the lime/fly ash samples achieved strength during the 28-day cure time evaluated for the test. The $5 \% / 10 \%$ lime/fly ash sample achieved the most strength of the samples tested, achieving a UCS of 84 psi after 28 days of cure. While this was the highest UCS obtained by the samples, it is not a significant difference from the $5 \% / 5 \%$ and $10 \% / 10 \%$ samples. The $10 \% / 5 \%$ lime/fly ash BSR gained the least strength during the test but still produced a material that was dry enough after 21 days to be classified as soil-like in nature. All of the samples evaluated were still wet at the 7-day test time, but they quickly dried between the 7- and 14-day testing.

Upon completion of these tests, it was decided to evaluate a fourth binder that used a mixture of cement and fly ash. Based on previous experience from other studies, it was decided to evaluate the same ratios of cement and keep the fly ash ratio at $10 \%$. Figure 10 presents the data for the $\mathrm{CI}$ for the cement/fly ash binders. 


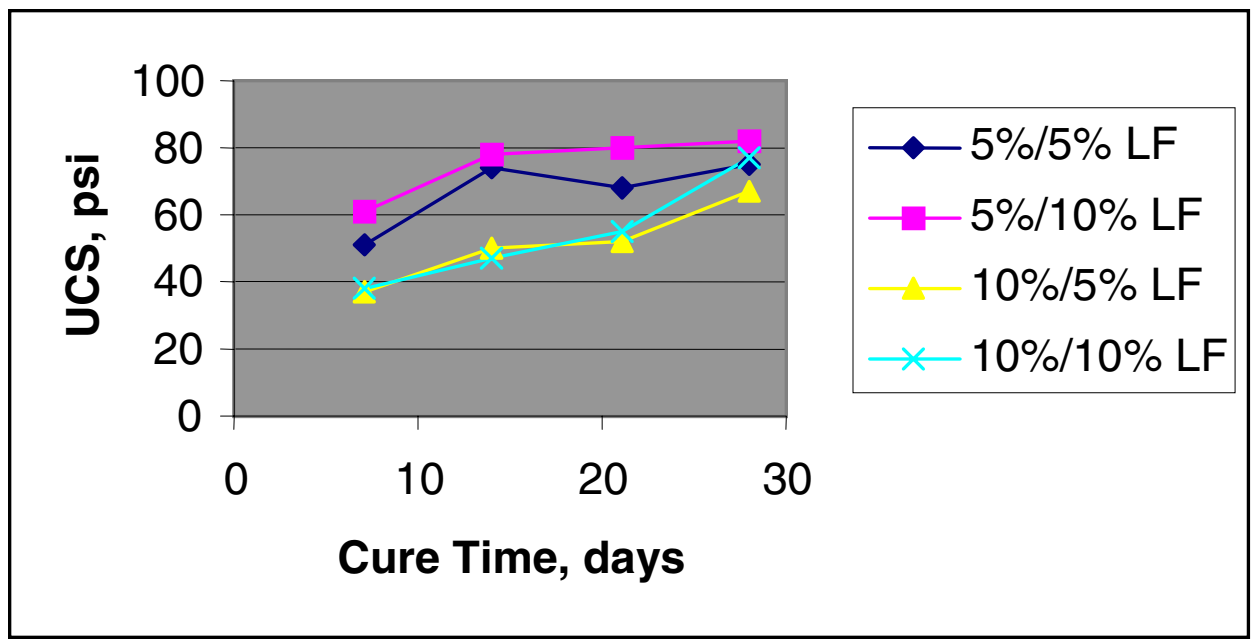

Figure 9. UCS results for the lime/fly ash BSRs

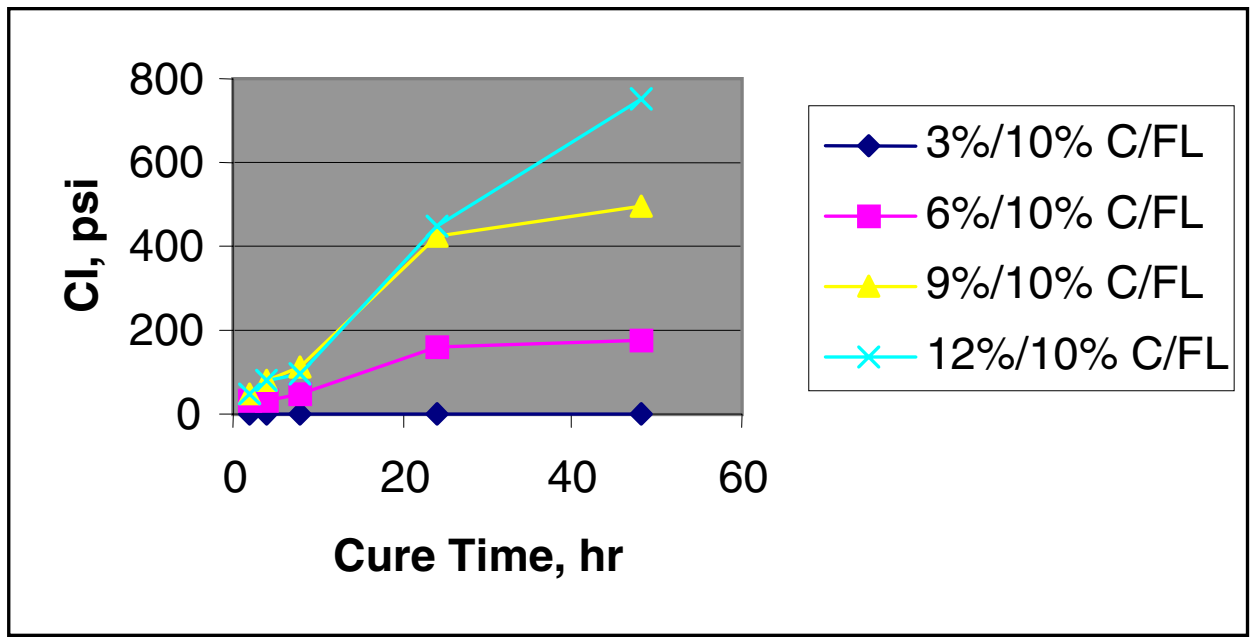

Figure 10. $\mathrm{Cl}$ results for the cement/fly ash BSRs

Figure 11 presents the data for the UCS for the cement/fly ash sample. Overall, the cement/fly ash sample performed well for producing a sample that had soil-like products. The $6 \% / 10 \%$ cement/fly ash sample produced a material that had a UCS of 85 psi after 28 days of cure and was very workable as a soil-like material. The $12 \% / 10 \%$ cement/fly ash sample was the only sample that gained excessive strength and would not be suitable for soil-like material.

Table 3 presents the data for the various physical tests that were preformed on the samples for the detailed evaluation portion of the study. The moisture content for the lower BSRs dropped to approximately 50\% from the $70 \%$ for the treated sediment. As expected, as the BSR was increased, the moisture content decreased due to the binder hydrating. The bulk density for almost all of the samples averaged around 87 pcf. The paint filter test was performed 


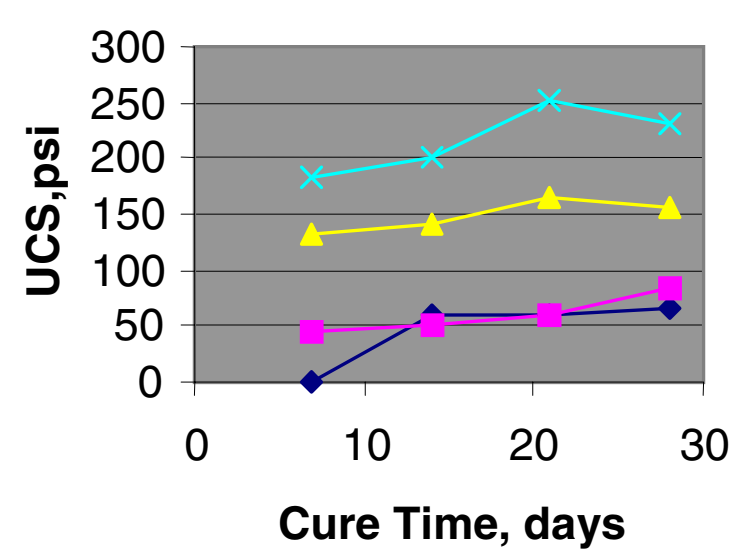

Figure 11. UCS results for the cement/fly ash BSRs

\section{Table 3}

\section{Results of Physical Testing of Treated Material}

\begin{tabular}{|c|c|c|c|c|c|c|c|}
\hline Sample BSR & $\begin{array}{l}\text { Moisture } \\
\text { Content, \% }\end{array}$ & $\begin{array}{l}\text { Bulk Den- } \\
\text { sity, pcf }\end{array}$ & $\begin{array}{l}\text { Specific } \\
\text { Gravity }\end{array}$ & Paint Filter & $\begin{array}{l}\text { Bleed } \\
\text { Water }\end{array}$ & Slump, in. & Permeability \\
\hline $3 \%$ cement & 56 & 84 & 2.6 & Failed & Present & 10 & \\
\hline $6 \%$ cement & 50 & 85 & 2.6 & Passed & None & 8 & \\
\hline $9 \%$ cement & 47 & 89 & 2.8 & Passed & None & 6 & \\
\hline $12 \%$ cement & 38 & 92 & 2.7 & Passed & None & 4 & \\
\hline $10 \%$ kiln dust & 56 & 88 & 2.5 & Failed & Present & 9 & 1.6E-04 \\
\hline $15 \%$ kiln dust & 52 & 87 & 2.6 & Failed & Present & 9 & $2.5 \mathrm{E}-04$ \\
\hline $20 \%$ kiln dust & 46 & 88 & 2.6 & Passed & None & 6 & \\
\hline $25 \%$ kiln dust & 41 & 89 & 2.6 & Passed & None & 5 & \\
\hline $5 \% / 5 \%$ L/FL & 54 & 87 & 2.7 & Failed & Present & 9 & 2.1E-04 \\
\hline $5 \% 10 \% \mathrm{~L} / \mathrm{FL}$ & 52 & 86 & 2.6 & Failed & Present & 6 & 5.4E-04 \\
\hline $10 \% / 5 \%$ L/FL & 50 & 85 & 2.8 & Passed & Present & 8 & 2.6E-05 \\
\hline $10 \% / 10 \% \mathrm{~L} / \mathrm{FL}$ & 41 & 86 & 2.8 & Passed & None & 5 & \\
\hline $3 \% / 10 \% \mathrm{C} / \mathrm{FL}$ & 50 & 85 & 2.6 & Failed & Present & 8 & \\
\hline $6 \% / 10 \% \mathrm{C} / \mathrm{FL}$ & 44 & 85 & 2.6 & Passed & None & 6 & 4.05E-05 \\
\hline $9 \% / 10 \% \mathrm{C} / \mathrm{FL}$ & 32 & 88 & 2.7 & Passed & None & 4 & \\
\hline $12 \% / 10 \% \mathrm{C} / \mathrm{FL}$ & 29 & 93 & 2.8 & Passed & None & 4 & \\
\hline
\end{tabular}


immediately after the mixing of the material was completed. The paint filter showed that the lower BSRs had water pass through the filter after mixing. This is probably because all of the water was not hydrated by the low binder ratios. As the BSRs increased, the water was used by the binders and did not pass the filter. Bleed water indicates the presence of water on the sample during the curing period of the sample. Once again the lower BSRs had water come to the top of the sample during the cure time, while the higher BSRs did not show the presence of water in the sample. Some of the samples, even though they failed the paint filter test and had bleed water during the initial cure, did not have water presence at the end of the cure time. These samples produced a product that was soil-like in nature and showed promise for meeting the criteria for the study. The slump (workability) test indicates how "liquid" the sample is immediately after mixing is completed. A 12-in. slump indicates that the sample is fluid and is not rigid enough to stand on its own. The lower BSRs were fluid and had high slumps, while the higher BSRs had some slump but could stand to a certain degree on their own. The cement/fly ash samples showed good workability for the BSRs evaluated. The permeability samples were chosen based on the samples chosen for leachability testing. These samples were compacted first and then subjected to the permeability evaluation. This compaction was done due to the voids that were present in the samples. The samples had to be extruded from the molds and broken up and compacted to form samples that could be subjected to permeability testing.

\section{Leachability}

Based on the results of the physical tests performed on the BSRs for the detailed evaluation, the BSRs that met the criteria for being soil-like in nature were evaluated for leachability. Table 4 presents the data for the TCLP performed on the samples. Although some of the samples failed the paint filter test immediately after mixing, $10 \%$ and $15 \%$ kiln dust, and 5\%/5\% and 5\%/10\% lime/fly ash, the samples had no water present at the end of the 28-day cure period.

The results of the TCLP for the metal contaminants show that all of the BSRs evaluated had low metals concentration in the TCLP leachate. Also, the data show that the untreated material had very low concentrations of metals contaminants in the TCLP leachate. Lead showed the most reduction in leaching potential when treated with the BSRs used for the study. The untreated sediment showed that lead leached from the sample at a concentration of $0.426 \mathrm{mg} / \mathrm{l}$. The treated samples reduced the concentration of lead in the TCLP leachate from $0.108 \mathrm{mg} / \mathrm{l}$ down to $0.045 \mathrm{mg} / \mathrm{l}$. Most of the other analyses show that the concentrations of metals dropped when the sediment was treated, but there was not a substantial statistical difference when compared to the untreated analysis.

The results for the PAHs and the PCBs show that all of the analytes were below the detection limit for all of the samples evaluated and the untreated sediment. Because of this result it is not possible to determine if the treatment applied to the sediment was effective in reducing the leachability of the contaminants. The only remark that can be made for these contaminants is that the 


\begin{tabular}{|c|c|c|c|c|c|c|c|}
\hline \multicolumn{8}{|c|}{$\begin{array}{l}\text { Table } 4 \\
\text { TCLP Results for the Detailed Evaluation Samples }\end{array}$} \\
\hline \multirow[b]{2}{*}{$\begin{array}{l}\text { Sample, } \\
\mathrm{mg} / \mathrm{l}\end{array}$} & \multicolumn{7}{|c|}{ BSR Ratio } \\
\hline & $10 \% \mathrm{KD}$ & $15 \% \mathrm{KD}$ & $5 \% / 5 \%$ L/F & $\begin{array}{l}5 \% / 10 \% \\
\text { L/F }\end{array}$ & $\begin{array}{l}10 \% / 5 \% \\
\text { L/F }\end{array}$ & $\begin{array}{l}6 \% / 10 \% \\
\text { C/F }\end{array}$ & Untreated \\
\hline Arsenic & $<0.02$ & $<0.02$ & 0.022 & 0.025 & 0.059 & 0.023 & 0.074 \\
\hline Barium & 0.400 & 0.457 & 1.19 & 1.01 & 0.415 & 0.563 & 0.533 \\
\hline Cadmium & 0.012 & 0.008 & 0.014 & 0.014 & $<0.005$ & 0.010 & 0.010 \\
\hline Chromium & 0.008 & 0.004 & 0.023 & 0.023 & 0.004 & 0.024 & 0.018 \\
\hline Lead & 0.079 & 0.062 & 0.108 & 0.106 & 0.045 & 0.094 & 0.426 \\
\hline Mercury & 0.0046 & 0.0029 & 0.0004 & $<0.0002$ & $<0.0002$ & $<0.0002$ & $<0.0002$ \\
\hline Selenium & $<0.050$ & $<0.050$ & $<0.050$ & $<0.050$ & $<0.050$ & $<0.050$ & $<0.050$ \\
\hline Silver & 0.0023 & 0.0037 & $<0.0010$ & $<0.0010$ & $<0.0010$ & $<0.0010$ & $<0.0010$ \\
\hline $\begin{array}{l}\text { Sample, } \\
\mu \mathrm{g} / \mathrm{l}\end{array}$ & $10 \% \mathrm{KD}$ & $15 \% \mathrm{KD}$ & $5 \% / 5 \%$ L/F & $\begin{array}{l}5 \% / 10 \% \\
\text { L/F }\end{array}$ & $\begin{array}{l}10 \% / 5 \% \\
\text { L/F }\end{array}$ & $\begin{array}{l}6 \% / 10 \% \\
\text { C/F }\end{array}$ & Untreated \\
\hline Naphth & $<5.1$ & $<5.1$ & $<05.1$ & $<<<5.1$ & $<<5.1$ & $<<<.1$ & $<<<.1$ \\
\hline Acenay & $<5.1$ & $<5.1$ & $<5.1$ & $<5.1$ & $<5.1$ & $<5.1$ & $<5.1$ \\
\hline Acenap & $<5.1$ & $<5.1$ & $<5.1$ & $<5.1$ & $<5.1$ & $<5.1$ & $<5.1$ \\
\hline Fluore & $<5.1$ & $<5.1$ & $<5.1$ & $<5.1$ & $<5.1$ & $<5.1$ & $<5.1$ \\
\hline Phenan & $<5.1$ & $<5.1$ & $<5.1$ & $<5.1$ & $<5.1$ & $<5.1$ & $<5.1$ \\
\hline Antrac & $<5.1$ & $<5.1$ & $<5.1$ & $<5.1$ & $<5.1$ & $<5.1$ & $<5.1$ \\
\hline Flanthe & $<5.1$ & $<5.1$ & $<5.1$ & $<5.1$ & $<5.1$ & $<5.1$ & $<5.1$ \\
\hline Pyrene & $<5.1$ & $<5.1$ & $<5.1$ & $<5.1$ & $<5.1$ & $<5.1$ & $<5.1$ \\
\hline Chryse & $<5.1$ & $<5.1$ & $<5.1$ & $<5.1$ & $<5.1$ & $<5.1$ & $<5.1$ \\
\hline Baanthr & $<5.1$ & $<5.1$ & $<5.1$ & $<5.1$ & $<5.1$ & $<5.1$ & $<5.1$ \\
\hline Bbflant & $<5.1$ & $<5.1$ & $<5.1$ & $<5.1$ & $<5.1$ & $<5.1$ & $<5.1$ \\
\hline Bkflant & $<5.1$ & $<5.1$ & $<5.1$ & $<5.1$ & $<5.1$ & $<5.1$ & $<5.1$ \\
\hline Bapyre & $<5.1$ & $<5.1$ & $<5.1$ & $<5.1$ & $<5.1$ & $<5.1$ & $<5.1$ \\
\hline I123Pyr & $<5.1$ & $<5.1$ & $<5.1$ & $<5.1$ & $<5.1$ & $<5.1$ & $<5.1$ \\
\hline Dbahant & $<5.1$ & $<5.1$ & $<5.1$ & $<5.1$ & $<5.1$ & $<5.1$ & $<5.1$ \\
\hline B-GHI-Py & $<5.1$ & $<5.1$ & $<5.1$ & $<5.1$ & $<5.1$ & $<5.1$ & $<5.1$ \\
\hline 2MeNaph & $<5.1$ & $<5.1$ & $<5.1$ & $<5.1$ & $<5.1$ & $<5.1$ & $<5.1$ \\
\hline PCB1016 & $<0.25$ & $<0.25$ & $<0.25$ & $<0.25$ & $<0.25$ & $<0.25$ & $<0.25$ \\
\hline PCB1221 & $<0.25$ & $<0.25$ & $<0.25$ & $<0.25$ & $<0.25$ & $<0.25$ & $<0.25$ \\
\hline PCB1232 & $<0.25$ & $<0.25$ & $<0.25$ & $<0.25$ & $<0.25$ & $<0.25$ & $<0.25$ \\
\hline PCB1242 & $<0.25$ & $<0.25$ & $<0.25$ & $<0.25$ & $<0.25$ & $<0.25$ & $<0.25$ \\
\hline PCB1248 & $<0.25$ & $<0.25$ & $<0.25$ & $<0.25$ & $<0.25$ & $<0.25$ & $<0.25$ \\
\hline PCB1254 & $<0.25$ & $<0.25$ & $<0.25$ & $<0.25$ & $<0.25$ & $<0.25$ & $<0.25$ \\
\hline PCB1260 & $<0.25$ & $<0.25$ & $<0.25$ & $<0.25$ & $<0.25$ & $<0.25$ & $<0.25$ \\
\hline
\end{tabular}


treatment applied to the sediment did not increase the leaching of the contaminants from the sediment.

The SBLT was also performed on the TCLP samples. Only the 1-, 3-, and 5-day samples were analyzed for the SBLT. The 2- and 4-day samples were kept refrigerated until the results of the 1-, 3-, and 5-day samples were complete.

Metals were the only contaminants that were detected in the SBLT extract.

Barium, chromium, and lead were the main metals that indicated the potential for leaching from the sample. Table 5 presents the metals data for the SBLT test for days 1, 3, and 5. Although some of the metals did appear in the SBLT leachate, the concentrations were at very low levels, and they did not appear to be increasing at a rapid rate during the test time. Barium had the highest concentrations in the SBLT leachate, but the levels were still well below the TCLP limit of $100 \mathrm{mg} / \mathrm{l}$. Overall, the SBLT test indicates that as time increases, the leachability of the contaminants from the sample does not substantially increase. This finding indicates that the BSRs applied to the sediment effectively decrease the potential for the contaminants to leach from the sample. It should be noted that

\begin{tabular}{|c|c|c|c|c|c|c|c|}
\hline \multicolumn{8}{|c|}{$\begin{array}{l}\text { Table } 5 \\
\text { Results of Metals Analysis for the SBLT Test } \\
\end{array}$} \\
\hline BSR Ratio & Day & $\begin{array}{l}\text { Arsenic } \\
\mathrm{mg} / \mathrm{l}\end{array}$ & $\begin{array}{l}\text { Barium } \\
\mathrm{mg} / \mathrm{l}\end{array}$ & $\begin{array}{l}\text { Cadmium } \\
\mathrm{mg} / \mathrm{l}\end{array}$ & $\begin{array}{l}\text { Chromium } \\
\mathrm{mg} / \mathrm{l}\end{array}$ & $\begin{array}{l}\text { Lead } \\
\mathrm{mg} / \mathrm{l}\end{array}$ & $\begin{array}{l}\text { Silver } \\
\mathrm{mg} / \mathrm{l}\end{array}$ \\
\hline \multirow{3}{*}{$10 \% \mathrm{KD}$} & 1 & $<0.02$ & 0.85 & $<0.005$ & 0.010 & 0.15 & $<0.001$ \\
\hline & 3 & 0.04 & 0.96 & 0.010 & 0.012 & 0.13 & $<0.001$ \\
\hline & 5 & 0.03 & 1.12 & 0.009 & 0.015 & 0.14 & 0.005 \\
\hline \multirow{3}{*}{$15 \% \mathrm{KD}$} & 1 & $<0.02$ & 1.1 & $<0.005$ & 0.008 & 0.13 & 0.002 \\
\hline & 3 & $<0.02$ & 1.36 & 0.006 & 0.011 & 0.12 & $<0.001$ \\
\hline & 5 & 0.03 & 1.85 & 0.008 & 0.023 & 0.135 & $<0.001$ \\
\hline \multirow[t]{3}{*}{$5 \% / 5 \%$ LF } & 1 & 0.03 & 1.88 & 0.008 & 0.036 & 0.10 & 0.003 \\
\hline & 3 & 0.05 & 2.56 & 0.012 & 0.045 & 0.14 & 0.005 \\
\hline & 5 & 0.06 & 3.97 & 0.015 & 0.087 & 0.14 & 0.005 \\
\hline \multirow[t]{3}{*}{$5 \% / 10 \%$ LF } & 1 & 0.055 & 1.62 & 0.012 & 0.030 & 0.098 & $<0.001$ \\
\hline & 3 & 0.081 & 1.84 & 0.018 & 0.051 & 0.12 & $<0.001$ \\
\hline & 5 & 0.09 & 1.97 & 0.016 & 0.078 & 0.11 & $<0.001$ \\
\hline \multirow[t]{3}{*}{ 10\%/5\% LF } & 1 & 0.05 & 0.95 & 0.011 & 0.014 & 0.058 & 0.002 \\
\hline & 3 & 0.072 & 1.20 & 0.023 & 0.042 & 0.13 & 0.0025 \\
\hline & 5 & 0.085 & 1.65 & 0.020 & 0.088 & 0.156 & $<0.001$ \\
\hline \multirow[t]{3}{*}{$6 \% / 10 \% \mathrm{CF}$} & 1 & 0.022 & 0.79 & $<0.005$ & 0.065 & 0.087 & $<0.001$ \\
\hline & 3 & 0.025 & 0.99 & $<0.005$ & 0.12 & 0.152 & $<0.001$ \\
\hline & 5 & 0.025 & 1.54 & 0.008 & 0.15 & 0.180 & $<0.001$ \\
\hline \multirow[t]{3}{*}{ Untreated } & 1 & 0.12 & 1.23 & 0.032 & 0.022 & 0.366 & $<0.001$ \\
\hline & 3 & 0.15 & 1.58 & 0.047 & 0.048 & 0.598 & $<0.001$ \\
\hline & 5 & 0.11 & 1.87 & 0.045 & 0.097 & 0.784 & $<0.001$ \\
\hline
\end{tabular}


while this is true, the untreated material did not leach a great deal of the contaminant from the material, but the concentrations were usually higher for the untreated than for the treated material. 


\section{Conclusions and Recommendations}

Sediment samples collected from the PSNS were shipped to WES for evaluation of $\mathrm{S} / \mathrm{S}$ on the samples. Various physical and chemical tests were performed on the untreated samples to develop baseline data for the comparison of the various binding agents applied to the sediment. Based on the evaluation performed on the treated sediment, the following conclusions can be drawn:

a. The untreated sediment had a moisture content of approximately $70 \%$ and was hard to physically handle. The material with the high moisture content would be difficult to handle during loading and off-loading for upland placement of the material.

b. Table 2 shows that the samples failed the paint filter test because free water passed through the filter. This is an important characteristic of the untreated material and would eliminate the material from being placed directly in an upland landfill environment. The material would first have to be dewatered, usually in a dewatering facility, and then excavated and hauled to a disposal site.

c. All of the binders used for the study (cement, kiln dust, lime/fly ash, and cement/fly ash) improved the handling characteristics of the sediment.

d. Although the handling characteristic of the sediment was improved, the low binder ratios used in the study did not always meet the treatment criteria. This was due to the fact that excessive water remained in some of the samples, and they did not produce a soil-like material. The higher binder ratios used sometimes produced a material that had excessive strength to be considered soil-like in nature and could not be classified as a workable material.

e. Samples were chosen for leachability analysis based on the physical characteristics of the material. These samples were $10 \%$ and $15 \%$ kiln dust; $5 \% / 5 \%, 10 \% / 5 \%$, and 5\%/10\% lime/fly ash; and 6\%/10\% cement/ fly ash. It should be noted that the lowest possible binder ratios were chosen in order to decrease the cost associated with the addition of the material to the sediment.

f. Although the kiln dust and 5\%/10\% and 5\%/5\% lime/fly ash samples had water present on the samples immediately after mixing and during 
the initial cure time, the water dissipated over the 28-day cure time and produced a material that was soil-like in nature. Because the material was soil-like and the lowest possible BSRs were chosen, the samples were evaluated for leachability of contaminants. Special provisions for curing of these samples, if chosen, would have to be incorporated before the sample could be placed in a disposal site.

g. All of the treated material passed the TCLP for regulated contaminants found in the sediment.

$h$. Metals were the only contaminants that were detected above the detection limit for the TCLP leachate.

$i$. Based on the handling characteristics of the material, the $6 \% / 10 \%$ cement/fly ash sample proved to be the optimal mixture to produce a product that met soil-like characteristics in the shortest amount of time. This formulation was chosen even though other mixtures showed promise for being used for the treatment of the material. The addition of lime, since it is a light material, usually increases the volume of material to be handled. The cement/fly ash mixture did not increase the strength of the material as compared to the cement binder but did show good results for the permeability evaluation.

Based on work that has been previously performed at New York/New Jersey Harbor, the treatment of the material could be done in a barge. The binders could be added to the dredged material and mixed in the barge and allowed to cure until the material could be removed and hauled to the disposal site. The average costs of treating the dredged material at the New York/New Jersey site averaged about $\$ 50.00$ per cubic yard of material. This cost included the dredging, treatment, hauling, and placement of the material. 


\section{References}

American Society for Testing and Materials. (1990). Annual book of ASTM standards. Vol 04.01, Construction, Cement, Lime, Gypsum, Philadelphia, PA.

. (1992a). Annual book of ASTM standards. Vol 04.01, Construction, Cement, Lime, Gypsum, Philadelphia, PA.

. (1992b). Annual book of ASTM standards. Soil and Rock, Dimension Stone, Geosynthetics, Philadelphia, PA.

American Society of Agronomy. (1965). "Methods for soil analysis: Part 1, Physical and mineralogical properties," Madison, WI.

Bricka, R. M., Holmes, T., and Cullinane, M. J. (1988). “An evaluation of stabilization/solidification of fluidized bed incinerator ash (KO48 and KO51)," Technical Report EL-88-24, U.S. Army Engineer Waterways Experiment Station, Vicksburg, MS.

Cullinane, M. J., Jones, L. W., and Malone, P. G. (1986). "Handbook for stabilization/solidification of hazardous wastes," EPA/540/2-86-001, U.S. Environmental Protection Agency, Risk Reduction Engineering Laboratory, Cincinnati, $\mathrm{OH}$.

Greiner, Inc. (1999). "Combined sampling and analysis plan addendum: Engineering properties and chemical mobility testing of marine sediments, Puget Sound Naval Shipyard, Bremerton, Washington," Seattle, WA.

Headquarters, Department of the Army. (1971). "Materials testing," Technical Manual 5-530, Section XV, Washington, DC.

Malone, P. G., and Jones, L. W. (1979). "Guide to the disposal of chemically stabilized and solidified wastes," SW-872, Office of Water and Waste Management, U.S. Environmental Protection Agency, Cincinnati, OH.

Malone, P. G., Jones, L. W., and Larson, R. J. (1980). "Guide to the disposal of chemically stabilized and solidified waste," SW-72, Office of Water and Waste Management, U.S. Environmental Protection Agency, Washington, DC. 
Myers, T. E., and Zappi, M. E. (1989). "New Bedford Harbor superfund project, Acushnet River Estuary engineering feasibility study; Report 9, Laboratory-scale application to solidification/stabilization technology," Technical Report EL-88-15, U.S. Army Engineer Waterways Experiment Station, Vicksburg, MS.

U.S. Environmental Protection Agency. (1982). "Interim status standards for owners and operators of hazardous waste treatment, storage, and disposal facilities," 47 FR 8307, Feb 25, 1982.

. (1986a). "Prohibition on the placement of bulk liquid hazardous waste in landfills: Statutory interpretive guidance," EPA 530 SW-86-016, OSWER Policy Directive 9487.00-24, Office of Solid Waste and Emergency Response, Washington, DC.

. (1986b). Federal Register. Vol 51, No. 142, Office of Solid Waste, Washington, DC.

. (1986c). Federal Register. Vol 55, No. 61, Office of Solid Waste, Washington, DC. 
Public reporting burden for this collection of information is estimated to average 1 hour per response, including the time for reviewing instructions, searching existing data sources, gathering and maintaining the data needed, and completing and reviewing the collection of information. Send comments regarding this burden estimate or any other aspect of this collection of information, including suggestions for reducing this burden, to Washington Headquarters Services, Directorate for Information Operations and Reports, 1215 Jefferson Davis Highway, Suite 1204, Arlington, VA 22202-4302, and to the Office of Management and Budget, Paperwork Reduction Project (0704-0188), Washington, DC 20503.

\begin{tabular}{|l|l|l|l}
\hline 1. AGENCY USE ONLY (Leave blank) & 2. $\begin{array}{l}\text { REPORT DATE } \\
\text { September } 2000\end{array}$ & $\begin{array}{l}\text { 3. } \\
\text { REPORT TYPE AND DATES COVERED } \\
\text { Final report }\end{array}$
\end{tabular}

4. TITLE AND SUBTITLE

5. FUNDING NUMBERS

An Evaluation of Solidification/Stabilization for Sediments from the Puget Sound

Naval Shipyard

6. AUTHOR(S)

Michael G. Channell

7. PERFORMING ORGANIZATION NAME(S) AND ADDRESS(ES)

U.S. Army Engineer Research and Development Center

Environmental Laboratory

3909 Halls Ferry Road, Vicksburg, MS 39180-6199

8. PERFORMING ORGANIZATION REPORT NUMBER

ERDC/EL TR-00-9

9. SPONSORING/MONITORING AGENCY NAME(S) AND ADDRESS(ES)

10. SPONSORING/MONITORING

Naval Facilities Engineering Service Center AGENCY REPORT NUMBER

Port Hueneme, CA 93041

11. SUPPLEMENTARY NOTES

12a. DISTRIBUTION/AVAILABILITY STATEMENT

12b. DISTRIBUTION CODE

Approved for public release; distribution is unlimited

13. ABSTRACT (Maximum 200 words)

Contaminated sediments from the Puget Sound Naval Shipyard were evaluated using solidification/stabilization technologies to determine if the material could have beneficial uses. Varying ratios of four binders (Portland cement, kiln dust, lime/fly ash, and Portland cement/fly ash) were evaluated on the material to determine if soil-like properties could be obtained from the sediment. Physical, chemical, and contaminant leaching tests were performed on the untreated and treated material to evaluate the potential of the treated material for use as a daily landfill cover or other beneficial use. The major focus of the study was to determine if any of the binders could produce a material that had soil-like properties and that reduced the leaching of contaminants from the product so that regulatory guidelines could be met for the use of the material.

14. SUBJECT TERMS

Beneficial use

Dredging

Sediments
Soil properties

Solidification/stabilization
15. NUMBER OF PAGES

36

16. PRICE CODE
17. SECURITY CLASSIFICATION OF REPORT UNCLASSIFIED
18. SECURITY CLASSIFICATION OF THIS PAGE UNCLASSIFIED
19. SECURITY CLASSIFICATION OF ABSTRACT 